\title{
OPTIMIZING REACTION CONDITIONS OF BIODIESEL PRODUCTION FROM WASTE COOKING OIL USING GREEN SOLID CATALYST
}

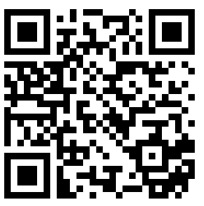

\author{
I Nengah Simpen ${ }^{* 1}{ }^{凶}$, I Made Sutha Negara ${ }^{2}$, Sofyan Dwi Jayanto ${ }^{3}$ \\ ${ }^{* 1,2,3}$ Department of Chemistry, Faculty of Mathematics and Natural Sciences, Udayana University, \\ Kampus Bukit Jimbaran, Badung, Bali, Indonesia
}

DOI: https://doi.org/10.29121/ijetmr.v7.i8.2020.764

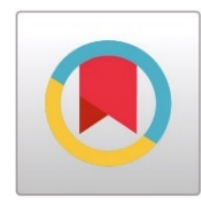

Article Citation: I Nengah Simpen, I Made Sutha Negara, and Sofyan Dwi Jayanto. (2020). OPTIMIZING

REACTION CONDITIONS OF

BIODIESEL PRODUCTION FROM

WASTE COOKING OIL USING GREEN

SOLID CATALYST. International

Journal of Engineering Technologies

and Management Research, 7(8),

65-71.

https://doi.org/10.29121/ijetmr.v7 i8.2020.764

Published Date: 31 August 2020

Keywords:

Biodiesel

Crab Shell

Cao/K2O-Tio2 Green Solid Catalyst

Waste Cooking Oil

\section{ABSTRACT}

Biodiesel production from waste cooking oil in two steps reaction of esterification and transesterification is low efficient, due to twice methanol consumption and need more reaction time. Optimizing reaction conditions of $\mathrm{CaO}$ as a matrix of solid catalyst prepared from crab shell (green $\mathrm{CaO}$ ) and modified by $\mathrm{K} 2 \mathrm{O} / \mathrm{TiO} 2$ for converting waste cooking oil to biodiesel have been carried out. Catalytic process of waste cooking oil to biodiesel took place in one step reaction of esterification and transesterification. The research result showed that optimum conditions in its one step reaction such as methanol to oil molar ratio was 9:1, amount of $\mathrm{CaO} / \mathrm{K} 20-\mathrm{TiO} 2$ catalyst to oil was $5 \%$ and reaction time of 60 minutes with biodiesel yield was $88.24 \%$. Physical and chemical properties of biodiesel which produced from one step reaction of esterification and transesterification of waste cooking oil were suitable with Indonesian National Standard (SNI-04$7182-2006$ ) namely density at $40 \mathrm{oC}$ of $850 \mathrm{~kg} / \mathrm{m} 3$, kinematic viscosity at $40 \mathrm{oC}$ of $3.32 \mathrm{cSt}$, water content of $0.046 \%$, iodine number of $59.25 \mathrm{~g}$ $\mathrm{I} 2 / 100 \mathrm{~g}$ and acid value of $0.29 \mathrm{mg} \mathrm{KOH} / \mathrm{g}$. Gas chromatography-mass spectrometry (GC-MS) analysis of biodiesel formed fatty acid methyl esters from conversion of waste cooking oil.

\section{INTRODUCTION}

Biodiesel is a mixture of mono alkyl esters produced from long chain fatty acids from biological feedstocks such as vegetable oils, animal fats and waste cooking oil in esterification and transesterification reactions with short chain of alcohol (methanol or ethanol) and using catalyst (Sivasamy et al., 2009; Math et al., 2010; Panudare and Rathod, 2015; Musa, 2016). The catalyst increased the rate of reaction to produce biodiesel (Abed et al., 2019). Waste cooking oil is a source feedstock to biodiesel production, because of economically prize and abundant sources. Besides, using waste cooking oil can solve disposal of its waste. Waste cooking oil has free fatty acids (FFAs) higher relatively, where FFAs $<15 \%$ for yellow grease and $>15 \%$ for brown grease due to content of FFAs $(>1 \%)$ causes saponification, it makes separation of biodiesel from mixture hardly, then obtaining less biodiesel yield (Mangesh and Ajay, 2006: Panudare and Rathod, 2015).

Generally, production of biodiesel is held in two steps reaction such as esterification by acid catalyst for reducing of FFAs content and transesterification by base catalyst for converting triglycerides (Zhang et al., 2010; Abed et al., 2019). In other hand, those process have weakness, namely need great amount of methanol and longer reaction time (Setiawan and Fatmir, 2012). Moreover, waste of base catalyst increased unburnt ash, whereas waste of acid catalyst makes corrosive in engine (Enweremadu and Mbarawa, 2009).

(C) 2020 The Author(s). This is an open access article distributed under the terms of the Creative Commons Attribution License, which permits unrestricted use, distribution, and reproduction in any medium, provided the original author and source are credited. 
Bifunctional solid catalyst enables to catalytic process in esterification and transesterification reactions by one step, so that biodiesel production from waste cooking oil in high FFAs can performed to simple step (Borges and Diaz, 2012). Besides, the solid catalyst application does not produce soaps through triglycerides saponification or FFAs neutralization (Guo and Fang, 2011). Salinas et al. (2010) studied activity of potassium catalyst with titanium supported $\left(\mathrm{K} / \mathrm{TiO}_{2}\right)$ for biodiesel production from canola oil. Converting canola oil to biodiesel of $100 \%$ with methanol to oil molar ratio of $36: 1,5$ hours reaction time, temperature of $70^{\circ} \mathrm{C}$ and amount of $6 \%$ catalyst (w/w oil). Loading potassium performed base active sites of titanium which has acid active sites. This catalyst described good activity, without initial preparation of feedstock. Istiadi et al. (2015) had explored and studied activity of $\mathrm{K}_{2} \mathrm{O} / \mathrm{CaO}$ $\mathrm{ZnO}$ catalyst for transesterification reaction soybean oil to biodiesel. The best catalyst performance showed by producing biodiesel yield of $81.8 \%$ with methanol to oil molar ratio of $15: 1$ and amount of $6 \%$ catalyst in temperature at $60^{\circ} \mathrm{C}$ (Istadi et al., 2015). Additional of $2 \% \mathrm{~K}_{2} \mathrm{O}$ in $\mathrm{CaO}-\mathrm{ZnO}$ increased catalytic activity to cause new raising surface area and basicity. Calcium oxide $(\mathrm{CaO})$ is solid catalyst usually used for triglycerides transesterification reaction to biodiesel production (Niju et al., 2016; Degfie et al., 2019). Activity of CaO catalyst can be advanced by adding promotor for increasing its surface basicity and acidity, increasing stability as well as surface area.

Base on that, the study held by optimizing one step reaction conditions of esterification and transesterification for biodiesel production from waste cooking oil using green solid catalyst of $\mathrm{CaO} / \mathrm{K}_{2} \mathrm{O}-\mathrm{TiO}_{2}$. Its reaction conditions optimization such as optimizing amount of catalyst to oil, optimizing methanol to oil molar ratio and optimizing reaction time.

\section{METHODS}

\subsection{SYNTHESIS OF CAO/ $\mathrm{K}_{2} \mathrm{O}-\mathrm{TIO}_{2}$ GREEN SOLID CATALYST}

$\mathrm{CaO}$ powder from crab shell was prepared and dried in oven at $110^{\circ} \mathrm{C}$ for 2 hours, then calcinated at $800^{\circ} \mathrm{C}$ for 5 hours. Dried green $\mathrm{CaO}$ was sieved to obtain a particle size of 100 mesh (Astuti et al., 2019). CaO as matrix was mixed with $10 \% \mathrm{~K}_{2} \mathrm{CO}_{3}(\mathrm{w} / \mathrm{w})$ in porcelain crush by solid state reaction. Homogeneous mixture of $\mathrm{CaO}$ and $\mathrm{K}_{2} \mathrm{CO}_{3}$ was cacined at $550^{\circ} \mathrm{C}$ for 3 hours (Degirmenbasi et al., 2015; Astuti et al., 2019) to form $\mathrm{CaO} / \mathrm{K}_{2} \mathrm{O}$. Furthermore, the $\mathrm{CaO} / \mathrm{K}_{2} \mathrm{O}$ was mixed with $\mathrm{TiO}_{2}$ at mass ratio of 3:1 homogeneously in the porcelain crush, then calcinated at $500^{\circ} \mathrm{C}$ for 5 hours (labelled by $\mathrm{CaO} / \mathrm{K}_{2} \mathrm{O}-\mathrm{TiO}_{2}$ ).

\subsection{OPTIMIZING CATALYTIC ACTIVITY TEST OF BIODIESEL PRODUCTION}

In initial step, waste cooking oil was filtered for reducing contaminant, continued heating to evaporate water in oil. Heating process at $110^{\circ} \mathrm{C}$ for 30 minutes. After process, oil was cooled till temperature range of $50-55^{\circ} \mathrm{C}(\mathrm{Bobade}$ and Kyade, 2012). The production of biodiesel in one step reaction of esterification and transesterification of waste cooking oil was conducted by using green solid catalyst of $\mathrm{CaO} / \mathrm{K}_{2} \mathrm{O}-\mathrm{TiO}_{2}$. Its reaction conditions optimizing amounts of catalyst to oil at 3, 5 and 7\%; methanol to oil molar ratios at 6:1, 9:1,12:1 and 15:1 as well as reaction time at 30, 60,120 and 180 minutes. All process were studied in reaction temperature at $65^{\circ} \mathrm{C}$. Produced biodiesel yield was calculated as percent yield $=\frac{\text { amount of produced biodiesel }}{\text { amount of oil }} \times 100$ (Abbah at al., 2016).

\section{RESULTS AND DISCUSSION}

\subsection{OPTIMIZING AMOUNT OF CATALYST}

Base on Figure 1, showed that the biodiesel yield increased in accordance with increasing amount of catalyst to oil, when additional from 3 to $5 \%$ but declining in 7\%. The amount of optimum catalyst influence to reactant mass transfer with catalyst. Additional amount of catalyst in mixture can increasing bulk hindrance, so that decline mass transfer on catalyst surfaces (Enciner et al., 2010). The result showed that optimum amount of catalyst was 5\%. 


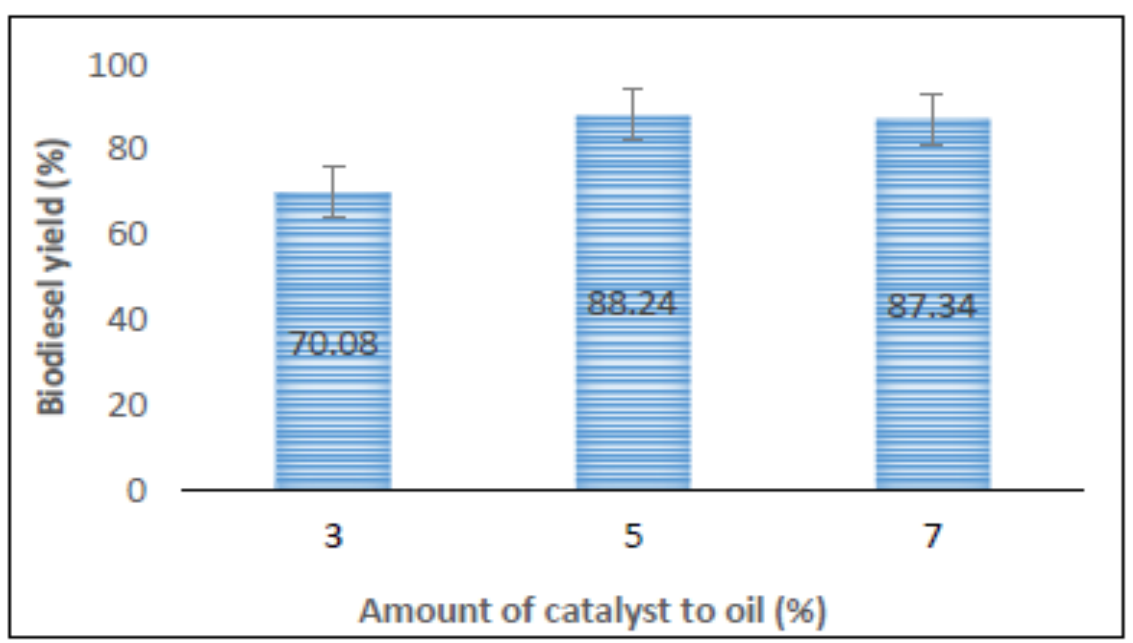

Figure 1: Effect of various amount of catalyst to oil for biodiesel yield

\subsection{OPTIMIZING TIME REACTION}

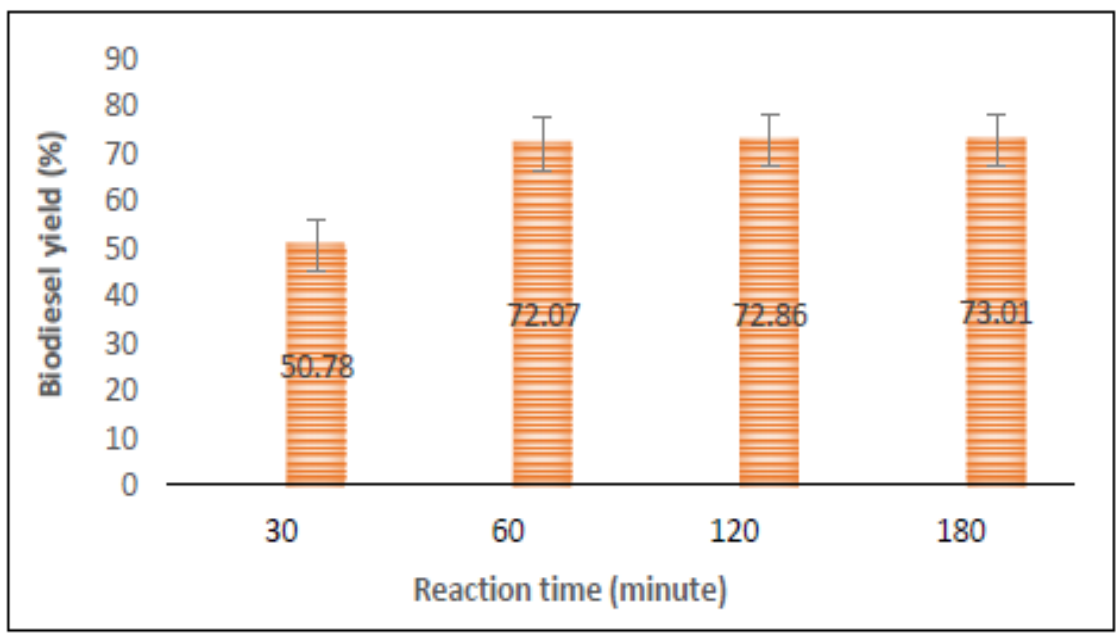

Figure 2: Effect of various reaction time for biodiesel yield

In Figure 2 described that at reaction time of 30 minutes was obtained the lowest biodiesel yield (50.78\%). It means that reaction time had not reached equilibrium. In reaction time of 30 to 60 minutes were obtained more biodiesel yield significantly (72.07\%). In reaction time of 120 to 180 minutes were obtained yield of $73.01 \%$. Fatty acid methyl esters production was faster in reaction time of 60 minutes, then declined till equilibrium was reached. It is explained that transesterification reaction is equilibrium. When equilibrium was reached additional of reaction time not affect to fatty acid methyl esters yield. Therefore, the optimum reaction time was 60 minutes.

\subsection{OPTIMIZING METHANOL TO OIL MOLAR RATIO}

Base on Figure 3, the highest biodiesel yield was obtained in methanol to oil ratio molar of 9:1 and 12:1 were $88.24 \%$ and $89.10 \%$, respectively. The methanol to oil molar ratio of $6: 1$ showed that reaction time was not in optimum, whereas it is higher 12:1 causes soluble glycerol in methanol, so that equilibrium position was replaced to reactant. Therefore, this process decreased the biodiesel yield (Mahreni, 2010). According to Encinar et al. (2010), transesterification reaction using solid catalyst on higher methanol to oil molar ratio caused three phase formed, because the methanol was not soluble in oil. Its three phase formed restricted contact inter-reactant in the initial step reaction, so that reaction time needed is more long duration to get equilibrium. Therefore, optimum methanol to oil molar ratio was 9:1. 


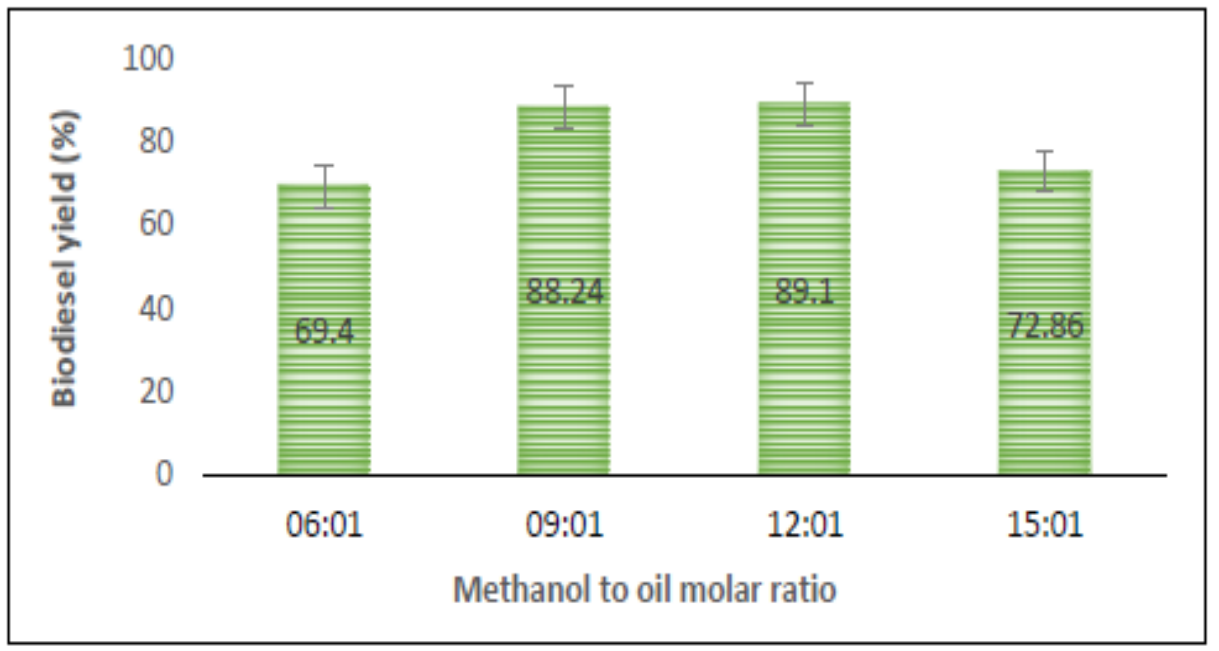

Figure 3: Effect of various methanol to oil molar ratio for biodiesel yield

\subsection{ANALYSIS OF BIODIESEL COMPOSITION}

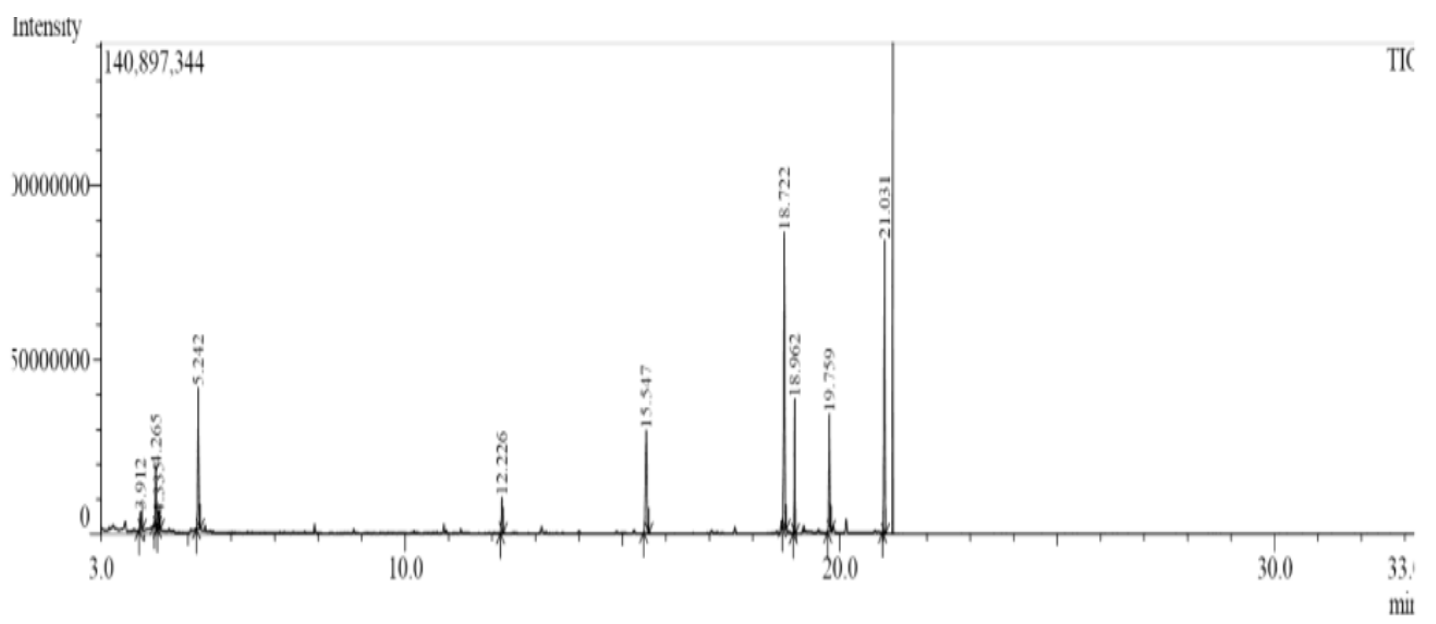

Figure 4: GC-MS analysis for biodiesel produced from waste cooking oil

Result of GC-MS analysis (Figure 4) described six main peaks and fragmentation pattern information. The highest peak was at retention time of 18.72 minutes. The fragmentation pattern information was identified as fatty acid methyl esters composition. It means that waste cooking oil was converted to fatty acid methyl esters (biodiesel) composition.

\subsection{ANALYSIS OF PHYSICAL AND CHEMICAL PROPERTIES OF BIODIESEL}

Physical and chemical properties of biodiesel on optimum reaction conditions of conversion result base on the SNI-04-7182-2006 (SNI, 2006) and the biodiesel standards of EN 14214 are presented in Table 1. The physical and chemical analysis result of produced biodiesel were suitable with the SNI-04-7182-2006 and the biodiesel standards of EN 14214. In analysis result of biodiesel density at $40^{\circ} \mathrm{C}\left(850 \mathrm{~kg} / \mathrm{m}^{3}\right)$ was agreement with the SNI-04-7182-2006 and lower than the standards of EN 14214 at $15^{\circ} \mathrm{C}$ (Essamlali et al., 2017). Density of biodiesel produced presented that contaminants in product such as catalyst waste, methanol, glycerol, soap, water and un-conversion of fatty acids to methyl esters (Setiawati and Fatmir, 2012). The more pure of biodiesel the lower its density, thus it was agreement with heating value and energy produced by diesel engine. The low density has high heating (Azis, 2011). 
Table 1: Physical and chemical properties of biodiesel from esterification and transesterification reactions of waste cooking oil base on the SNI-04-7182-2006

\begin{tabular}{|c|c|c|c|}
\hline Property & Produced biodiesel & $\begin{array}{c}\text { Biodiesel Standards } \\
\text { (SNI-04-7182-2006) }\end{array}$ & Biodiesel standards of EN 14214 \\
\hline Density at $40^{\circ} \mathrm{C}\left(\mathrm{kg} / \mathrm{m}^{3}\right)$ & 850 & $850-890$ & $860-900\left(\right.$ at $\left.15^{\circ} \mathrm{C}\right)$ \\
\hline Viscosity at $40^{\circ} \mathrm{C}(\mathrm{cSt})$ & 3.32 & $2.3-6.0$ & $3.50-5.00$ \\
\hline $\begin{array}{c}\text { Iodine number } \\
\left(\mathrm{mg} \mathrm{I}_{2} / 100 \mathrm{~g}\right)\end{array}$ & 59.25 & Max 115 & Max 120 \\
\hline Acid value $(\mathrm{mg} \mathrm{KOH} / \mathrm{g})$ & 0.29 & Max 0.5 & $<0.5$ \\
\hline Water content $(\%)$ & 0.046 & Max 0.05 & $<0.05$ \\
\hline
\end{tabular}

Viscosity is an important parameter for biodiesel application in diesel engine. Viscosity connected with flow rate of fuel through injector that affecting as an indicator of atomization degree in injection burning room (Lestari et al., 2017; Abed et al., 2019). The range is made sure that injecting biodiesel to easier burning room. The highest viscosity will cause be $3 \mathrm{~d}$ atomization of fuel and oxygen so that burning process unideal. Kinematic viscosity of produced biodiesel (3.32 cSt) which is suitable with its SNI and the standards of EN 14214 .

Iodine number determine amount of double bond of fatty acid in biodiesel is connecting with stable oxidative state. Higher iodine number as an indicator of lower oxidation stability, so that oxidation and precipitation in engine is easier (Abed et al., 2019). Iodine number of produced biodiesel (59.25 mg I2/100g) that is suitable with its SNI and the standards of EN 14214.

Acid value related with corrosion rate of engine. When acid value increasing, the corrosion risk of engine is increasing too. Acid value of produced biodiesel from converting waste cooking oil still in range quality standard of the SNI and the standards of EN 14214. It indicated that converting process was effective.

Water content is a parameter to indicate the biodiesel quality. High water content in biodiesel cause to reduce heat burning, hydrolysis and corrosion trigger (Setiawati and Fatmir, 2012; Abed et al., 2019). Water content of produced biodiesel was in range standard of the SNI and the standards of EN 14214.

\section{CONCLUSIONS}

Optimum one step reaction condition of esterification and transesterification of waste cooking oil to biodiesel using green catalyst of $\mathrm{CaO} / \mathrm{K}_{2} \mathrm{O}-\mathrm{TiO}_{2}$, such as methanol to oil molar ratio was $9: 1$, amount of $\mathrm{CaO} / \mathrm{K}_{2} \mathrm{O}-\mathrm{TiO}_{2}$ catalyst to oil was $5 \%$ and reaction time of 60 minutes with biodiesel yield was $88.24 \%$. The physical and chemical properties of biodiesel were suitable with the SNI-04-7182-2006. The GC-MS analysis of biodiesel showed that fragmentation pattern information identified as fatty acid methyl esters composition.

\section{SOURCES OF FUNDING}

This research supported by the Institute of Research and Community Service of Udayana University through Faculty of Mathematics and Natural Sciences.

\section{CONFLICT OF INTEREST}

None.

\section{ACKNOWLEDGMENT}

Thanks to the Institute of Research and Community Service of Udayana University, through Faculty of Mathematics and Natural Sciences for the Research Grant of Penelitian Unggulan Program Studi scheme year 2019. 
Optimizing Reaction Conditions of Biodiesel Production from Waste Cooking Oil Using Green Solid Catalyst

\section{REFERENCES}

[1] Abed, K.A., Gad, M.S., Morsi, A.K.E., Sayed, M.M. and Elyazeed, S.A. Effect of biodiesel fuels on diesel engine emissions. Egyptian Journal of Petroleum. 28. 2019. 183-188.

[2] Abbah, E.C., Nwandikom, G.I., Egwuonwu, C.C. and Nwakuba, N.R. Effect of reaction temperature on the yield of biodiesel from neem seed oil. American Journal of Energy Science. 3(3). 2016. 16-20.

[3] Astuti, N.K.D., Simpen. IN. dan Suarsa. IW. Transesterifikasi minyak biji karet (hevea brasiliensis) menggunakan katalis heterogen cangkang kepiting limbah seafood termodifikasi K20. Jurnal Kimia. 13(1). 2019. 1-8.

[4] Aziz, I., Nurbayti, S. dan Ulum, B. Pembuatan produk biodiesel dari minyak goreng bekas dengan cara esterifikasi dan transesterifikasi. Valensi. 2(3). 2011. 443-448.

[5] Bobade, S.N. and Khyade, V.B. Detail study on the properties of pongamia pinnata (karanja) for the production of biofuel. Research Journal of Chemical Sciences. 2(7). 2012. 16-20.

[6] Borges, M.E. and Díaz, L. Recent developments on heterogeneous catalysts for biodiesel production by oil esterification and transesterification reactions: a review. Renewable and Sustainable Energy Reviews. 16. 2012. 2839-2849.

[7] Degfie, T. A., Mamo, T.T. and Mekonnen, Y.S. Optimized biodiesel production from waste cooking oil (WCO) using calcium oxide (CaO) nanocatalyst. Scientific Reports-Natureresearch. 9. 2019. 1-8.

[8] Degirmenbasi, N., Coskun, S., Boz, N. and Kaylon, D.M. Biodiesel synthesis from canola oil via heterogeneous catalyst using functionalizes cao nanoparticles. Fuel. 153. 2015. 620-627.

[9] Encinar, J.M., Gonzalez, J.F., Pardal, A. and Martinez, G. Rape oil transesterification over heterogeneous catalyst. Fuel Processing Technology. 91. 2010.1530-1536.

[10] Enweremadu, C.C. and Mbarawa, M.M. Technical aspects of production and analysis of biodiesel from used cooking oil-a review. Renewable and Sustainable Energy Reviews. 13. 2009. 2205-24.

[11] Essamlali, Y. Amadine, O. Larzek, M. Len, C. and Zahouily, M. Sodium modified hydroxyapatite: highly efficient and stable solid-base catalyst for biodiesel production. Energy Convertion and Management. 149. 2017. 355367.

[12] Guo, F. and Fang, Z., Biodiesel production with solid catalysts. Biodiesel Feedstocks and Processing Technologies. 2011. 1-21.

[13] Istadi, I., Sebastianus, A., Prasetyo. and Nugroho, T.S. Characterization of K2O/CaO-ZnO catalyst for transesterification of soybean oil to biodiesel. Procedia Environmental Sciences. 23. 2015. 394-399.

[14] Lestari, K.A.T., Simpen, I N. dan Santi, S.R., Optimasi rasio molar dan waktu reaksi pada pembuatan biodiesel dari minyak biji malapari (Pongamia pinnata L.) dengan katalis abu sekam padi termodifikasi litium. Cakra Kimia. 5(1). 2017. 43-51.

[15] Mahreni. Peluang dan tantangan komersialisasi biodiesel-review. Jurnal Eksergi. 10(2). 2010. 15-26.

[16] Mangesh, G.K. and Ajay, K.D. Waste cooking oil-an economical source for biodiesel: a review. Industrial and Enginering Chemistry Research. 45. 2006. 2901-2913.

[17] Math, M.C., Kumar, S.P. and Chetty, S.V. Technologies for biodiesel production from used cooking oil - a review. Energy for Sustainable Development. 14. 2010. 339-45.

[18] Musa, I.A. The effects of alcohol to oil molar ratios and the type of alcohol on biodiesel production using transesterification process. Egyptian Journal of Petroleum. 25. 2016. 21-31.

[19] Niju, S., Begum, K.M.M.S. and Anantharaman, N. Enhancement of biodiesel synthesis over highly active CaO derived from natural white bivalve clam shell. Arabian Journal of Chemistry. 9. 2016. 633-639.

[20] Panudare, D.C. and Rathod, V.K. Application of waste cooking oil other than biodiesel: review. Irranian Journal of Chemical Engineering. 12(3). 2015. 55-76.

[21] Salinas, D., Guerrero, S. and Araya, P. Transesterification of canola oil on potassium-supported TiO2 catalysts. Catalysis Communications. 11. 2010.773-777.

[22] Setiawati, E. dan Fatmir, E. Teknologi pengolahan biodiesel dari minyak goreng bekas dengan teknik mikrofiltrasi dan transesterifikasi sebagai alternatif bahan bakar mesin diesel. Jurnal Riset Industri. 6(2). 2012. 117-127.

[23] Sivasamy, A., Cheah, K.Y., Fornasiero, P., Kemausuor, F., Zinoviev, S. and Miertus, S., Catalytic applications in the production of biodiesel from vegetable oils. ChemSusChem. 2. 2009. 278-300.

[24] SNI. Persyaratan mutu dan metode uji biodiesel. 04-7182-2006. Badan Standarisasi Nasional. 2006. 
I Nengah Simpen, I Made Sutha Negara, and Sofyan Dwi Jayanto

[25] Zhang, J., Chen, S., Yang, R. and Yan, Y. Biodiesel production from vegetable oil using heterogeneus acid and alkali catalyst. Fuel. 89. 2010. 2939-2944. 